\title{
Aleksandra Zalewska-Królak* \\ iD https://orcid.org/0000-0002-8503-4845 \\ THE PARTICIPATION OF CHILDREN IN SOCIAL RESEARCH. INTRODUCTION TO THE ISSUE
}

\begin{abstract}
The perspective of childhood studies has existed in science since the 1990s. Currently, it is considered as a paradigm. The article concerns one of the assumptions of this theoretical orientation - the participation of children in research. The analysis of the concept includes both positive and critical stances expressed in the subject literature. The text contains an analysis of the main assumptions of childhood studies and their relationship to the participatory approach to research. Moreover, it presents types of participatory research with children, considering the degree of their participation. The article refers to numerous examples of both research and specific techniques applied.

Keywords: participation of children in research, agency, child as an active social actor, child research, research with children, forms of participation, participatory tools, childhood studies, new sociology of childhood.
\end{abstract}

\section{Introduction}

In this article I would like to focus on one of the foundations of the childhood studies paradigm, namely children's participation in research. However, even with this limitation of scope the issue is still very broad, therefore the text serves merely as an introduction to the problem, highlighting key issues. ${ }^{1}$ The author is committed to the critical approach to the issue, reflecting upon whether, how and when the participation of a child in social research should be taken into consideration. The analysis will begin by indicating the assumptions on which the theoretical orientation of childhood studies is built. The author will consider how they

* MA, Doctoral Student at the Institute of Applied Social Sciences, University of Warsaw, The Department of Culture Research Method, Nowy Świat 69, 00-927 Warszawa, e-mail: aleksandra.zalewska@uw.edu.pl

${ }^{1}$ Due to the introductory character of this text, numerous references to research websites can be found herein, together with research reports, as well as examples of employing various techniques which researches may find interesting. The structure of this article does not enable the author to discuss them in detail, therefore, multiple information is implied in the notes. 
relate to the postulate of participatory research, which is considered to be "the gold standard" (Hammersley 2017). Thereafter, the reasons justifying children's participation in research will be analyzed. Moreover, the conditions enabling and inhibiting conducting participatory research with children, as well as the potentials and limitations resulting from this form of methodological approach, will be investigated.

\section{The cornerstone of participatory research with children}

The answer to the question: "who is a child, and how to define childhood?" has changed over the course of centuries (Ariès 2010). A significant turning point from the perspective of social research occurred in the 1980s and 1990s (Hammersley 2017; Thomas 2017; Brzozowska-Brywczyńska 2014; Mayall 2013; Radkowska-Walkowicz, Reimann 2018b) and was connected with legislative changes on the one hand, and the emergence of a new paradigm of childhood studies, on the other (Prout, James 1990).

Creating the Convention on the Rights of the Child (UNCRC), and its subsequent ratification, played a major role in the process of enabling child participation in social research (Broström 2012). This document became an inspiration for creating other significant legislative documents, e.g. the African Charter on the Rights and Welfare of the Child in Africa (1990) and the European Convention on the Exercise of the Children's Rights (2000) (Brzozowska-Brywczyńska 2014). For research focused on taking into account child participation, Article 12 of the UNCRC, known also as the participatory article, is of special importance (Horgan et al. 2017), as it underlines that a child has the right to "forming his or her own views the right to express those views freely in all matters affecting the child, the views of the child being given due weight in accordance with the age and maturity of the child" (Brzozowska-Brywczyńska 2014: 12). Giving a child the right to express their views equipped the researchers who employ participatory methods with a vital argument and tool (Horgan 2017). From that moment on, more importance has been attached to what children say, to their perspective, and to their knowledge regarding the world. The need to express oneself and to be listened to was also pointed out. In addition, the individual perspective has been highlighted (Mason, Bolzan 2010).

Another breakthrough was achieved with the emergence of the assumptions on which the paradigm of childhood studies was created. Previously, the prevailing view had been that children and childhood were marginalised in research (Hammersley 2017; Coyne, Carter 2018). This primarily resulted from the conviction that chilren are to some extent incomplete, not fully developed in cognitive, mental and emotional terms (Hammersley 2017). An adult person was considered to be a fully developed human. Children were stranded in the process of becoming an adult. This assumption influenced the way a child was perceived 
- as unable to comprehend and describe the surrounding world (Hood, Kelley, Mayall 1996). There was a common belief that children were not capable of providing a precise description of their experiences, thus, they failed to provide accurate information regarding their own lives (Coyne 1998). This attitude legitimized validating research with the children's parents or guardians who, according to the prevalent beliefs at the time, possessed the ultimate knowledge regarding their children's experiences (Morrow, Richards 1996). As a result, it turned out that there was no research that could portray the social reality as seen by children. These voices of children are often recognized as muted voices ( $\mathrm{Rad}$ kowska-Walkowicz, Reimann 2018a: 38). There were certain cases where the results of research conducted on the adult population constituted the basis on which the children's world was modified (Coyne, Carter 2018). Jens Qvortrup highlighted "the conceptual homelessness of childhood" (Qvortrup 2007, cited in: Warzywoda-Kruszyńska 2014: 127). He pointed out that lack of data concerning this social group is disquieting. In research, structural forms, such as class, gender or race, refer only to the reality of adults (Warzywoda-Kruszyńska 2014: 127), which according to the author, is a manifestation of marginalising children (Qvortrup 1997). Therefore, together with his fellow associates, he carried out a project Childhood as Social Phenomenon (Qvortrup 1993), whose aim was to underline the importance of children's presence in society. The author asserts that childhood is a category equal to any other category, and thus it should be studied and analysed by researchers from various fields of interest. Qvortrup mentions that this approach is an expression of taking children seriously (Qvortrup 1997).

Undoubtedly, the first shifts in the subjective perception of children were possible due to the legal solutions which enabled scientists to take part in discussions with ethics committees regarding the participation of children in research. Nevertheless, the foundation of what such research should look like was "the groundbreaking" (Coyne, Carter 2018) text by Allison James and Alan Prout (Prout, James 1990), which characterised a child as an expert on the knowledge regarding their own life. One of the theoretical bases which gave birth to social studies was social constructivism. Childhood is a socially constructed project (James, Prout 1997), which means that it is changeable. It is influenced by the sociocultural context, actively co-created by individuals. What is more, in line with the objectives of constructivism, reality cannot be investigated in an objective way, as we only have access to our own interpretation of reality (Clark 2004). This is why children's individual experiences are of vital importance. Therefore, research should focus on childhood, children's relations and culture, for their own sake, not understood as a consequence of external influences (Broström 2012: 257). James and Prout considered children to be social actors whose knowledge (Mayall 2008) is significant from the scientific point of view. The word "science" is crucial, due to its the implicit associations. This is because knowledge, contrary 
to the statements including opinions or observations, emphasizes the subjective role of a child, draws attention to the fact that a child has in his or her memory experiences regarding the past, and though these experiences are probably not as vast as in the case of an adult, because of the number of years they have lived, they still amount to what is called knowledge. This approach is distinct from considering statements uttered by children as only temporary, and therefore perceived as momentary and changeable, and for this reason disdained (Mayall 2008, cited in: Radkowska-Walkowicz, Reimann 2018a).

Childhood studies outlines the image of a child who is an actor and a social subject at the same time (Hammersley 2017). The former role refers to the causative agency in the context of a child's everyday life, it highlights the fact of his or her decision-making and the impact these decisions make. The latter role refers to social reality, draws attention to the active role of a child in shaping the social world. In the social sciences one can encounter the term "Great Divide" (Fuchs 2001: 25), which describes the division between an approach focused on the micro and macro subject and object and the social structure opposed to subjective activity. In childhood studies this division is also visible, however, to a lesser extent. For example, the Scandinavian tradition is more focused on structure, and the Anglo-Saxon tradition is more ethnographical, and thus oriented towards the social actor (Esser et al. 2016: 54). However, neither tradition excludes the impact of both macro and micro perspective and the structure and subject on expanding knowledge regarding social reality. The author who attempted to capture the dual nature of this structure was Anthony Giddens (2003). In the theory of structuration, he propounds the duality of structure, which is confirmed by the constitution of agents and structures (Giddens 2003: 65). The structural properties of the social system do not exsist independently from action, they constantly interweave with its productions and reproductions (Giddens 2003: 425). The correlation between an agent and structure was also an object of interest of Prout and James (Prout, James 1990) in the text considered to be one of the founding texts of childhood studies. The authors refer therein to both Qvortrup and Giddens.

A certainly noticable term reffering to numerous theoretical approaches on whose theses the childhood studies paradigm has been created is that of "agency". As pointed out by Florian Esser, there is no single definition of this term (E s s e r et al. 2016: 54). It has become taken-for-granted and omnipresent. Nevertheless, along with the advance of various approaches within the framework of childhood studies (the paradigm that from the outset was based on interdisciplinarity), agency may take various forms, moreover, it is a multidimensional concept. Participatory research is a gold standard of childhood studies, grounded on the assumption that children are causative agents. The understanding of agency therefore has a direct influence on research practice, this is why a critical approach towards this concept constitutes a vital challenge for researchers (see Esser et al. 2016; Holland et a1. 2010; Morrison et al. 2019). 


\section{What is participatory research about?}

In the Polish language, "participation" refers primarily to economy, it places emphasis on cooperation, which involves both costs and profit. ${ }^{2}$ In the context of social research, the key element is the issue of cooperation, and costs and benefits are derivative elements. To participate is to take part (Gallacher, Gallagher 2008: 507). Active participation is crucial. However, two questions emerge here: "what does it mean and how does it translate into the social research?".

Children's participation in research is based on the childhood studies assumptions. It concentrates on the child's individual knowledge regarding the world, treating this knowledge as legitimate data regarding social reality. It enables children to talk about the issues concerning them, and it highlights the active role children play in the whole research process. The most common methods in this paradigm are qualitative. Participatory research does not only aim at eliciting the vital data, from the researcher's point of view; its task is to describe selected elements of the social reality, the children's way of perceiving the world.

The gradual departure from objectifying a child in favour of granting them a subjective role, enabled a child to be considered as a rightful agent of the research process. Two separate terms were distinguished: ${ }^{3}$ research on children and research with children, with the latter taking account of their participation and enabling them to express their views. Participatory research assures agency, respecting their subjectivity, therefore, the source literature is dominated by the confidence that in the epistemological context this approach is superior to a more traditional attitude (Gallacher, Gallagher 2008: 499, 501). In the post-modern world, children are perceived as active entities and participants whose right to research is legally determined (Broström 2012: 257). Nowadays, there are some voices that encourage one more step to be taken, and introduce a new term - research by children (Thomas 2017: 160). The level of children's participation in research is still a widely discussed issue. Numerous publications mention the pitfalls connected with a naive and unreflective approach towards research conducted by children (see e.g. Christensen, Prout 2002; Gallacher, Gallagher 2008; Sargeant, Harcourt 2012; Thomas 2017; Hammersley 2017; Christensen, James 2017).

Korrie De Koning and Marion Martin (1996) assert that there is no single definition of participatory research. However, they can be divided into three categories: researchers and the researched community take part in the whole research

${ }^{2}$ In Stownik Języka Polskiego we can find the following definition: "to jointly bear the costs of a certain endeavour or to share the profits", https://sjp.pwn.pl/szukaj/partycypacja.html (accessed 20.07.2019).

${ }^{3}$ More about this shift can be found in the subchapter of a book Being Participatory: Researching with children and young people (Coyne, Carter 2018: 3-4) entitled Past views of children and childhood. 
process, the subjects become de facto researchers; researchers design tools and the subject community assist in collecting data; society cooperates with an NGO organization (De Koning, Martin 1996). All the definitions mentioned above may be referred to specific examples of participatory research with children. ${ }^{4}$

From the participatory research with children one can distinguish research models which function under a specific name: Community-Based Participatory Research (CBPR) and Participatory Action Research (PAR) (Wilkinson, Wilkinson 2018). The starting point for the former is an issue that is significant for a community. The approach aims at combining knowledge with undertaking activities. More and more opportunities for funding this research model arise, as it is believed that the conclusions drawn from CBPR can be utilised by the policies e.g. regarding education or health. The PAR model, on the other hand, derives from combining participatory research and action research: it aims at implementing a social change (Cahill 2007).

There are a number of methods that are applicable when distinguishing types of participatory research. What they all have in common is the fact that they refer primarily to the level of children's agency. Although the term passive participation might seem like an oxymoron, in the source literature the terms active and passive participation can be encountered (Grover 2004; Sinclair 2004). Samantha Punch (2002) explains that "active" participation methods are those where children are actively engaged, not passively responsive. In this sense "active participation" implies both intentionality (conscious will) and performativity (doing something) (Punch 2002: 337).

The most popular tool for determining the level of children's engagement in the research process is Hart's Ladder:

Rung 8: Children and adults share decision-making

Rung 7: Children lead and initiate action

Rung 6: Adults initiate but share decision-making with children

Rung 5: Children are consulted and informed about decisions

Rung 4: Children are assigned and informed

Rung 3: Children are tokenized

Rung 2: Children are decoration

Rung 1: Children are manipulated

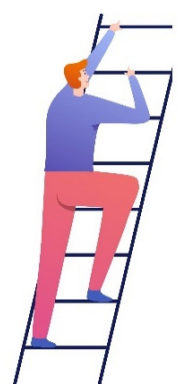

Figure 1. Hart's Ladder

Source: Hart 1997, cited in: Coyne, Carter 2018: 11. Image from canva.com

\footnotetext{
${ }^{4}$ An example referring to all these definitions may be the project "The City of Children", within which since the 1990s. participatory projects including children have been conducted, enabling their participation on different levels. More on this subject can be found at: https://www.lacittadeibambini. org/en/ (accessed: 20.07.2019).

${ }^{5}$ More information regarding utilizing these methods can be found in the chapter Principles of Participatory Research of the book Being Participatory: Researching with Children and Young People (Coyne, Carter 2018: 21-31).
} 
The ladder does not depict a hierarchical division of the types of participatory research from the most effective model to the least effective one. It is more about presenting successive levels regarding children's participation in a research. The successive rungs of the ladder symbolize the levels of participation granted to children. The first three rungs relate to truly passive participation. The next ones present different stages of active participation. The top of the ladder presents full cooperation between children and adults. The tools can be also utilized when designing participatory research in order to determine the level of children's agency at a certain stage of the research process. It is also advantageous in the course of selecting concrete research tools.

Reflecting upon children's participation in research, the definitional issue is worth mentioning. Children constitute a vast, heterogeneous group (varied in terms of age and gender, and social, economic and cultural capital). Therefore, employing this term involves making a serious generalization that one has to be aware of. For example, the age of children who participate in research has an influence on the specific nature of the process. In treaty provisions (i.e. the United Nations' Convention of Human Rights) a child is defined as every person under the age of eighteen. In the source literature and numerous reports ${ }^{6}$ one can encounter a distinction between children and young people. ${ }^{7}$ However, it may be noted that the number of reports concerning the latter group is significantly larger. The people defined by this term are frequently divided into two subgroups: eleven to sixteen years of age and seventeen to twenty/thirty years of age (Thomas 2017: 161). Consequently, children are understood to be ten years old and under. In Poland, people aged eleven and above are considered to be teenagers (Fatyga 2004). This distinction plays a significant role, as it enables the nature of the research to be comprehended. The majority of the research conducted on the assumptions of childhood studies refer to the former age group. Nevertheless, I am of the opinion that due to the definitional doubts it is worth mentioning who exactly took part in the research, as it is contributes to the transparency of the researcher's skills and tools. An objection against this assumption might be the argument that this type of approach can reinforce imagining a child as a person in the process of growing up, in other words as incomplete, striving for maturity. It seems to me, however, that lack of this information is detrimental from the practical point of view, especially in the context of the adopted methodological approach and the employed techniques.

${ }^{6}$ E.g. the report "Children and clinical research: ethical issues". The link to the chapter related to this subject: http://nuffieldbioethics.org/report/children-and-clinical-research-ethical-issues/ whats-different-about-research-with-children-and-young (accessed 16.07.2019).

${ }^{7}$ https://www.gov.pl/web/edukacja/praca-mlodziez-raport (accessed 1.09.2020). 


\section{The aims of children's participation in social research}

The decision regarding whether children should participate in research entails numerous problems, encompassing both legislative issues and practical obstacles. Including children in research involves obtaining various types of written permission, ${ }^{8}$ moreover, a researcher needs to be knowledgeable about the applicable law, as not every procedure can be applied in every country. For instance, in Poland there are one hundred and sixty-two documents that refer to the rights of children: fifty-three from the United Nations and the League of Nations, one hundred and nine from the Council of Europe (Arczews ka 2017). With regard to the practical obstacles, they appear at every stage of a study and are most frequently connected with how to keep the balance between children's agency and their welfare (Brzozowska-Brywczyńska 2014; Water 2018; Sargeant, Harcourt 2012; Zalewska-Królak 2019). Why, despite numerous obstales, is it worth conducting participatory research with children?

The paradigm of childhood studies indicates many arguments in favour of advantages of listening to children, attempting to understand them and treating children as rightful creators of social space: children as "beings" rather than "becomings" (Gallacher, Gallagher 2008: 502). The participatory approach is emancipatory and democratic (Gallacher, Gallagher 2008: 499). Taking into consideration a child's perspective implies treating them as active agents, possessing certain competences (Coyne, Carter 2018: 5). Participatory research is based on a theoretical vision of a child from the perspective of their power, not deficiency (Coyne, Hallström, Söderbäck 2016). It is assumed that the proper selection of methods will enable a child, even a two-year-old, to express themselves (Coyne, Carter 2018: 5).

On numerous occasions Qvortrup emphasized the necessity of legally obliging nations to collect data concerning children, as he believed that allowing children to voice their opinion, which involves obtaining access to their knowledge regarding the surrounding reality, might improve the quality of their life, by appropriate adjustments of public policies. The European Union's measures can serve as an interesting example. In 2015, an evaluation regarding children's participation in the EU was conducted. ${ }^{9}$ Particular attention was given to legislative issues, public policies, and real practices. The studies show that reliable, comparable and official data concerning the situation of children in the Member States is still lacking. However, issues pertaining to legislation have improved. The report reveals that children in the EU take part in projects related to sport, leisure and culture on a more and more frequent basis. Nevertheless, the number of examples

${ }^{8}$ E.g. a guardian's written permission, GDPR permission.

${ }^{9}$ https://op.europa.eu/en/publication-detail/-/publication/3f3c50b2-6a24-465e-b8d174dcac7f8c42/language-en/format-PDF/source-search (accessed 15.09.2020). 
of activities engaging children in the decision-making process is still not satisfactory. Tonucci also highlights this problem. ${ }^{10}$ Another example of delving into this subject is the study involving children and teenagers from the European Union (Warzywoda-Kruszyńska 2014), revealing the still prevailing theses of Qvortrup, asserting that: "in modern societies children and youth as a collective element of a social structure are discriminated against in terms of access to resources and opportunities to satisfy their needs in comparison to the generation of adults" (Warzywoda-Kruszyńska 2014: 138) despite numerous measures, including the European concept of investing in children. ${ }^{11}$ This is why, regardless of the number of years that have passed, the main aim of the participatory approach to research with children is to strengthen their position in the social reality, in other words to foster children's empowerment. As pointed out by Jill Clark (2004), due to the marginalisation of children as a social group, participatory methods may often be the only ones that enable them to express their opinions.

A significant aim of participatory research is acknowledging children's competences and their right to agency. The employment of participatory techniques enables them to actively structure their knowledge about themselves (Gallacher, Gallagher 2008: 503). Mary Kellett (2005) enumerates the positive outcomes of this approach. She also indicates that it also increases their self-esteem, which affects their self-confidence. What is more, children get accustomed to the fact that they have the right to speak out and that, moreover, their opinion is considered valuable. By taking part in the project, especially preceded by methodological workshops, children learn universal skills, such as critical thinking, ethical awareness, teamwork, and successful communication. These are the competences that have an impact on their position in the world. Active participation aims at battling against children's marginalisation and at the democratisation of research concerning their reality. Caitlin Cahill (2004) also points out that children, reflecting upon problems that concern them, gain tools necessary to build knowledge about themselves, as well as altering the surrounding world. The reflections of Maja Brzozowska-Brywczyńska regarding children's citizenship are of particular interest in this context. This author points out that: "children have a right to be listened to only when they speak the safe language of participatory projects" (Brzozow ska-Brywczyńska 2014: 24). Their rights as citizens should concern everyday life and take into consideration their social presence in the world. One has to bear in mind, however, the pitfall of being tempted to create perfect future citizens in the process of participatory research (Rose 1999). This because it is based on "the »futurology « conception of the child's agency" (Brzozowska-Brywczyńska 2014: 24).

${ }^{10}$ More information regarding this subject can be found in the film "The goal is to transform children's words into politics", created by the author, https://www.youtube.com $/$ watch? $\mathrm{v}=\mathrm{vFxt} 5 \mathrm{nLen} 1 \mathrm{w}$ (accessed 16.07.2019).

${ }^{11} \mathrm{https} / /$ ec.europa.eu/social/main.jsp?catId=1060\&langId=en (accessed 15.09.2020). 
Sonja Grover (2004) asserts that participatory methods are recognized as the ones that create more authentic knowledge about children's subjective reception of reality. Cahill (2004) underlines that they generate greater knowledge than other techniques. Therefore, participation is both an aim and a tool in the ethical challenge of empowering children (Gallacher, Gallagher 2008: 501). Participatory research can become a tool that counteracts marginalisation, allowing the hitherto "muted" voices to be heard. However, when considering such research, the issue of who conducts it, how, and in what context, is not without significance. ${ }^{12}$

\section{How to conduct participatory research with children?}

The key points that constitute participatory research with children are: cocreation, relation, choice, reflexiveness, flexibility, time, space and the cultural and geopolitical context (Clark 2008; Holland et al. 2010; Raffety 2015). Only an approach that takes into consideration all the crucial elements enables participatory research to be conducted effectively.

Co-creation, that is, creating something together, refers to cooperation between adults and children. The key aspect of this context is power. Participatory methods are to prevent the master-student relation. Children can perform the same functions as adults; there is no hierarchical division. However, in society, power - as understood by Foucault - is unavoidable, i.e. power that is not necessarily associated with an economic model, but is rather present on a micro scale, in everyday small instances of persuasion (Gallacher, Gallagher 2008). Therefore, constant reflection upon children's subjectivity, a reflective approach regarding boundaries of this subjectivity, and methods of respecting these boundaries are still necessary elements of the whole research process. It is also worth taking into consideration certain inequalities that may become apparent in a group of collaborating children (the age gap, gender, economic, social and cultural capital) and trying to mitigate these differences by consciously changing certain activities.

The knowledge of both adults and children is considered fully legitimate. In the context of the research process, it has to be emphasized that adult researchers are also people who need to be properly prepared. This applies in the case of children as well (Kellett 2005). This approach, on the one hand, acknowledges their competences as future researchers, and on the other leaves a great deal of room for active operation. Children are equipped with tools that can be utilized in the fu-

${ }^{12}$ The organisations that support researchers' development or share vital data concerning participatory research are for instance: Children's Research Center, http://wels.open.ac.uk/research/ childrens-research-centre (accessed 16.07.2019); The Centre for Children and Young People's Participation in University of Central of Lancashire, https://www.youtube.com/watch? $\mathrm{v}=\mathrm{Wx} 4 \mathrm{CbfpzFG}$ A\&feature=youtu.be (accessed 16.07.2019). 
ture, in accordance with their own assumptions. This solution serves as a response to various ethical objections connected with the research conducted by children. The pioneering place that strove for enabling children to acquire competences in order to become researchers was The Children's Research Center, ${ }^{13}$ which operated under the aegis of the Open University in England. A film prepared by the organization explaining the idea of participatory research is recommended viewing. ${ }^{14}$ Another institution fulfilling a similar role is The Centre for Children and Young People's Participation at the University of Central Lancashire. ${ }^{15}$

A significant element of the collaboration is creating relations between researchers, irrespective of their age. Cooperation based on respect enables the whole research team to benefit from the competences of particular persons. Researchers complement each other, and thanks to that they are able to create a broader description of the studied aspect of social reality. A noteworthy example is the perennial project "The City of Children". ${ }^{16}$ It constitutes another example of changes that were initiated at the beginning of the 1990s. In 1991, Francesco Tonucci included children in the project, as he was aiming at changing the image of the city. He believed that the observations made by children are essential and would significantly broaden the perspective of what a city should look like. The researchers' cooperation with the children resulted in the creation of over one hundred "cities of children" in the following countries: Italy, Spain, Argentina, Uruguay, Colombia, Mexico, Peru, Chile, Lebanon, Turkey. ${ }^{17}$ The project is ongoing.

An essential condition of ethically conducted participatory research with children is the choice given to children. One aspect of this is informed consent. In case of the participatory element, ensuring that the consent is intentionally granted is particularly challenging. Children should understand what role they will play in research (see Radkowska-Walkowicz, Reimann 2018b; Zalewska-Królak 2019). Nevertheless, involving children's agency at every single stage of the research makes its accurate identification impossible. The nature of this type of a research is unpredictable (Gallacher, Gallagher 2008: 513). Determining in advance specifically what the reaserch will deal with, what it will look like, and what use will be made of it in the future, is simply not feasible. This is because children will answer these questions in the course of the research process, together with

${ }^{13}$ The institution's website is a mine of knowledge regarding both the assumptions of children's participatory research, as well as the applied techniques. Of vital importance are also reports of the research conducted available under the tab: Recent Research by Children \& Young People, http://wels.open.ac.uk/research/childrens-research-centre (accessed 16.07.2019).

${ }^{14} \mathrm{https}: / / \mathrm{www} . y o u t u b e . c o m /$ watch? $\mathrm{v}=\mathrm{Wx} 4 \mathrm{CbfpzFGA} \&$ feature=youtu.be (accessed 16.07.2019).

$15 \mathrm{https} / /$ www.uclan.ac.uk/research/explore/groups/centre_young_people_participation.php (accessed 16.07.2019).

${ }^{16}$ The project's website: https://www.lacittadeibambini.org/en/ (accessed 16.07.2019).

17 The map presenting the location of "cities of children" is available: https://www.lacittadeibambini. org/en/international-network/ (accessed 16.07.2019). 
adults. As emphasised by the researchers of Interdisciplinary Childhood Studies Team ${ }^{18}$ good practice regarding children's participation involves creating visual information regarding the essence of the research, the people who conduct the research, the purpose of the research, and the role of children in the research ${ }^{19}$ (Radkowska-Walkowicz, Reimann 2018b). The langauge and the form of the presented information have to be adjusted to the needs and ablities of children, as well as their guardians or other people who take part in the research. In participatory research it is not possible to take all the necessary data into consideration. Obviously, it depends on the adopted level of participation. In its broadest scope, there could be hardly any option to give answers to any of the abovementioned issues, since there are children who actively decide in the course of the research process what they would like to deal with, how to do this, and what purpose their research will serve. In this case, however, it is possible to indicate who will be co-creating the research, as far as the adults are concerned. It is also crucial to determine whether children will have an opportunity to take part in methodological workshops, and if so, who will conduct them. An interesting idea for solving this situation and giving the broadest description of the proceedings is to explain what participatory research is. A significant element of this information seems to be creating a code of rights ${ }^{20}$ that are granted to the participants of the research. In my opinion, the most troublesome element is specifiyng what choice is in terms of participatory research, and emphasizing that on each level of the research a child is able to decide to what extent they want to be involved in this project. It also needs to be underlined that a child can resign from the research at any point. These guidelines are unquestionably connected with numerous problems associated with conducting participatory research with children, as children cannot be held responsible for it. Here a question emerges: "who should be held responsible?" (Hammersley 2017). This constitutes a broad issue for further consideration.

An interesting example of presenting information in a visual form to children is a film ${ }^{21}$ created by The Nuffield Council on Bioethics in cooperation with Mosaic Films. This animation results from a project ${ }^{22}$ regarding health research with children and young people. Apart from the value of its form, which can be an inspiration for creating a film regarding the participatory research with children, the assumptions of this project are of vital importance. In order to actually answer

${ }_{18} \mathrm{http}: / /$ childhoods.uw.edu.pl/ (accessed 5.07.2019).

19 An example of a leaflet informing both children and their guardians about the research is presented in Radkowska-Walkowicz, Reimann 2018b: 59-60.

${ }^{20}$ An inspiration for creating such a code may be The Code of Good Practices proposed by the Interdisciplinary Childhood Studies Team: http://childhoods.uw.edu.pl/664-2/ (accessed 5.07.2019).

${ }^{21}$ The film is available at: https://www.youtube.com/watch?v=6yaKwLG_vlE (accessed 10.07.2019).

${ }^{22}$ The report on the project "Children and clinical research: ethical issues" is available at: http://nuffieldbioethics.org/project/children-research (accessed 10.07.2019). 
the questions of potential participants of research with children, the researchers decided to take the participatory methods into account. ${ }^{23}$ The visual form has one more advantage - it engages a larger group of recipients, as it does not require reading skills, and through employing two senses - sight and hearing - it is more accessible for people with disabilities.

I am of the view that the most vital assumption of the participatory research is its reflectiveness. This is directly connected with all the remaining guidelines. When it comes to the aspect of cooperation and relation, an adult researcher needs to reflect constantly upon the issue of power. Considering this issue cannot take place in isolation from ethics or the cultural and geopolitical situation of the place where the research is being conducted, as it has a certain impact on it. For instance, nowadays, due to the fact that a great deal of participatory research takes place in schools, it has an influence on the research topics (Kellett 2005). A significant feature for a researcher who works with children is their flexibility. A researcher should be prepared for numerous changes and be ready to confront them. There are significant costs associated with this, however - the unpredictable period of time a researcher could spend conducting the research. Therefore, this aspect is worth considering beforehand and certain borders should be set.

Utilizing participatory methods requires a great deal of creativity, in order to facilitate children's active engagement in the research process, and for them to describe how they perceive the world and what meaning they assign to it. Participatory research is, after all, a process based on co-creating meanings (Tisdall, Punch 2012). As Loris Malaguzzi (1993) points out, there are hundreds of children's langauges. The researcher's role is to decipher them. O'Kane (2000) notices that participatory methods require children to be truly engaged in doing something; they should actually "handle things" not "just talk" (O'Kane 2000: 140). The techniques that may serve as an example of this postulate include: creating maps or giving tours around a certain neighbourhood (see: "The City of Children" project ${ }^{24}$ ), children taking photographs (Barker, Weller 2003; Greenfield 2004; Burke 2005), creating collages, and writing diaries (Radkowska-Walkowicz, Reimann 2018a). In view of the cultural context, making use of modern technologies seems to be an interesting idea. They constitute a part of the children's world. On the other hand, one should take into consideration the limitations connected with a lack of certain tools, in order to avoid marginalisation. The following are examples of interesting practices: creating radio broadcasts (Weller

${ }^{23}$ More on this issue can be found at: http://nuffieldbioethics.org/report/children-and-clinicalresearch-ethical-issues/inviting-children-and-young-people-to-take-part (accessed 16.07.2019).

${ }^{24} \mathrm{https} / /$ www.lacittadeibambini.org/en/project/ (accessed 15.09.2019). 
2006), films, ${ }^{25}$ telephone applications, ${ }^{26}$ and digital storytelling. ${ }^{27}$ Cheryl Greenfield (2004) points out, however, that utilizing specific prompts, photographs in this case, can serve as a starting point for conversations that could provide significant research data. Similar observations were made by Favretto, Fucci and Zaltron, who give examples of how to use vignettes, ${ }^{28}$ or Reimann, who employs the method of drawing. ${ }^{29}$ Well-designed tools should be customized to fit children who participate in research (Coyne, Carter 2018: 2), should be based on their strengths, and should take into consideration the cultural and geopolitical context.

\section{When to consider children's participation in research?}

Kellett (2005) points out that research conducted by children introduces new value to science. According to this researcher, children see the world through a different lens and ask questions that adults would never come up with. Children's ideas are characterized by freshness and ingenuity (Matthews 1996). Because of their age, children have immediate access to the world of their peers, moreover, they are perceived by them in a different way than extraneous adult researchers, who are often seen as intruders. Children's input at each stage of the research process, including posing research questions, preparing tools, research execution, data analysis and drawing conclusions, is original and valuable. Kellett pays particular attention to the formulation of research questions. The fact that children get interested in certain issues results from their interests and concerns, and can be easily neglected by adults. An interesting example is the project Hey, I'm nine, not six ${ }^{30}$, which describes a playground for girls who seem to be much younger than they really are (Thomas 2017: 169). Nevertheless, the decision as to whether children should be involved in research needs to be followed by meeting the requirements entailed by this methodological approach.

At this point the issue of finding a balance between safety and children's agency needs to be considered once again. On the one hand, children's coopera-

${ }^{25} \mathrm{https}: / /$ www.youtube.com/watch?v=6yaKwLG_vlE (accessed 16.07.2019).

${ }^{26}$ Map My Community is an interesting project that uses a smartphone application to research new trends concerning city development in India. More about the project can be found on the website: http://www.new-urbanism-india.com/map-my-community.php (accessed 16.07.2019), taking a look at the application is also worthwhile.

${ }^{27} \mathrm{http}: / /$ participatesdgs.org/?s=digital+storytelling (accessed 16.07.2019).

${ }^{28}$ Exemplary vignettes together with the method's description can be found in Radkowska-Walkowicz, Reimann 2018b: 89-91.

${ }^{29}$ Exemplary drawings, together with a description of the method can be found in Radkowska-Walkowicz, Reimann 2018b:138-148.

${ }^{30}$ Thomas provides the example of this project, referring to a conference presentation of A. Carlini, E. Barry (2005) "Hey I'm nine not six!". Paper presented at Spotlight on Young Researchers Conference, The Open University, 18th April. 
tion throughout the whole research process is recommended (depending on the level of participation involved). However, on the other hand, one cannot forget that the researcher bears the responsibility for any undesirable effects of the research and is obliged to ensure the child's wellbeing (which can be interpreted in various ways (see Arczew ska 2017)). The research conditions need to guarantee the safety of the participants yet enable their active operation. In this text I mainly refer to the opportunity of expressing oneself, the implementation of activities; however, one needs to bear in mind that silence is also information and lack of activity, refraining from it, can constitute a form of action (see Spyrou 2016). The recommendations regarding safety and agency are both contextual, to a great extent. They depend, among other things, on the legislative arrangements that are applicable in a given country. The responsibility for taking into account these guidelines lies with the researcher. A common pitfall is placing too much emphasis on safety, which could convert participation into tokenism.

It has to be borne in mind that participatory research often takes the form of major projects that last for months. During the preparatory stage the geopolitical and cultural context need to be taken into account. Children's participation in research can be influenced by, for instance, the weather and, depending on cultural conditions, a permanent place indoors may need to be found. The character of this place may have an influence on the research process. For instance, the school context has a major potential for reproducing the power relationships that existing in the education system of a given country. Cooperation with NGO organisations is a common practice, as they not only provide gathering places, but they also play the role of doorkeepers, who make it easier to enter the research area.

An interesting issue regarding research that anticipates the active participation of children is its future accessibility (Thomas 2017). This is not understood merely as its publication, but also enabling perusal of the publication's content. An example of such efforts are two children's versions of book publications by the Interdisciplinary Childhood Studies Team (Radkowska-Walkowicz, Reimann 2018a; Radkowska-Walkowicz, Reimann 2019).

\section{Conclusion}

The issue of children's participation in research constitutes undoubtedly one of the foundation stones of childhood studies. However, its analysis requires referring to the remaining assumptions and theoretical principles on which this paradigm has been created. It is a particularly broad and complex problem; therefore, multiple publications address this issue. Lesley-Anne Gallacher and Michael Gallagher call participatory research with children an immature methodology (Gallacher, Gallagher 2008: 513). This approach certainly requires further discussion, however, its positive sides should not be underestimated. The increase 
in the amonut of literature regarding this issue bespeaks the desire to continue the debate. The aims of children's participation in research are strongly highlighted, taking into consideration the reflection on their form and conditions that I hopefully managed to point out in this text. The ever increasing number of projects conducted, together with the critical deliberations on advantages and disadvantages of children's participation, demonstrate the reflectiveness of researchers and enables development of this methodological approach.

\section{Bibliography}

Arczewska M. (2017), Dobro dziecka jako przedmiot troski społecznej, Nomos, Kraków.

Ariès P. (2010), Historia dzieciństwa: dziecko i rodzina $w$ czasach ancien régime'u, transl. M. Ochab, Aletheia, Warszawa.

Barker J., Weller S. (2003), "Is it fun?” developing children centred research methods, "International Journal of Sociology and Social Policy", vol. 23(1/2), pp. 33-58.

Broström S. (2012), Children's participation in research, "International Journal of Early Years Education", no. 20(3), pp. 257-269.

Brzozowska-Brywczyńska M. (2014), Dziecięce obywatelstwo: Kilka refleksji na marginesie idei dziecięcej partycypacji, "Acta Universitatis Lodziensis. Folia Sociologica”, no. 49, pp. $11-27$.

Burke C. (2005), "Play in focus": children researching their own spaces and places for play, "Children, Youth and Environments", vol. 15(1), University of Cincinnati, https:/www.jstor. org/stable/10.7721/chilyoutenvi. 15.1.0027

Cahill C. (2004), Defying gravity? Raising consciousness through collective research, "Children's Geographies", vol. 2(2), pp. 273-286.

Cahill C. (2007), Including excluded perspectives in participatory action research, "Design Studies", vol. 28(3), pp. 325-340.

Christensen P., Prout A. (2002), Working with ethical symmetry, "Childhood: A Global Journal of Child Research", vol. 9(4), pp. 477-497.

Christen sen P., J a m e s A. (eds.) (2017), Research with Children. Perspectives and practices, 3rd ed., Routledge, London.

Clark A. (2008), How to listen to very young children: the mosaic approach, "Child Care in Practice", vol. 7(4), pp. 333-341.

Clark J. (2004), Participatory research with children and young people: philosophy, possibilities and perils, "Action Research Expeditions", no. 4, pp. 1-18.

Coyne I. (1998), Researching children: some methodological and ethical considerations, "Journal of Clinical Nursing", vol. 7(5), pp. 409-416.

Coyne I., Carter B. (eds.) (2018), Being Participatory: Researching with children and young people. Co-constructing knowledge using creative techniques, Springer International Publishing, Switzerland.

Coyne I., Hallström I., Söderbäck M. (2016), Reframing the focus from a family-centred to a child-centred care approach for children's healthcare, "Journal of Child Health Care", vol. 20(4), pp. 494-502.

De Koning K., Martin M. (1996), Participatory Research in Health: Issues and experiences, NPPHCN, Johannesburg.

Esser F., Baader M.S., Betz T., Hungerland B. (2016), Reconceptualising Agency and Childhood: New perspectives in childhood studies, Routledge, London. 
Fatyga B. (ed.) (2004), “Biała księga” młodzieży polskiej: diagnoza sytuacji młodych Polaków jako podstawa strategii państwa dla młodzieży, Ministerstwo Edukacji Narodowej i Sportu, Warszawa.

Fuchs S. (2001), Beyond agency, "Sociological Theory", vol. 19(1), pp. 24-40.

Gallacher L.-A., Gallagher M. (2008), Methodological immaturity in childhood research?, "Childhood: A Global Journal of Child Research", vol. 15(4), pp. 499-516.

Giddens A. (2003), Stanowienie społeczeństwa: zarys teorii strukturacji, transl. S. Amsterdamski, Zysk i S-ka, Poznań.

Greenfield C. (2004), Transcript: "can run, play on bikes, jump on the zoom slide, and play on the swings"; exploring the value of outdoor play, "Australian Journal of Early Childhood", vol. 29(2), pp. 1-5.

Grover S. (2004), Why won't they listen to us? On giving power and voice to children, "Childhood: A Global Journal of Child Research", vol. 11(1), pp. 81-93.

Hammersley M. (2017), Childhood Studies: a sustainable paradigm?, "Childhood: A Global Journal of Child Research", vol. 24(1), pp. 113-127.

Hart R.A. (1997), Children's Participation: The theory and practice of involving young citizens in community development and environmental care, Earthscan, London.

Holland S., Renold E., Ross N.J., Hillman A. (2010), Power, agency and participatory agendas: a critical exploration of young people's engagement in participative qualitative research, "Childhood: A Global Journal of Child Research", vol. 17(3), pp. 360-375.

Hood S., Kelley P., Mayall B. (1996), Children as research subjects: a risky enterprise, "Child \& Society", vol. 10(2), pp. 117-129.

Horgan D. (2017), Child participatory research methods: attempts to go "deeper", "Childhood: A Global Journal of Child Research", vol. 24(2), pp. 245-259.

Horgan D., Forde C., Martin S., Parkes A. (2017), Children's participation: moving from the performative to the social, "Children's Geographies", vol. 15(3).

James A., Prout A. (1997), Constructing and Reconstructing Childhood, Routledge, London.

Kellett M. (2005), Children as active researchers: a new research paradigm for the 21st century?, "NCRM Methods Review Papers", no. 003.

Malaguzzi L. (1993), For an education based on relationships, "Young Children", vol. 49(1), pp. 9-13.

Mason J., Bolzan N. (2010), Questioning understandings of children's participation: applying a cross-cultural lens, [in:] B. Percy-Smith, N. Thomas (eds.), A Handbook of Children and Young People's Participation: Perspectives from theory to practice, Routledge, London, pp. 11-23.

Matthews G.B. (1996), The Philosophy of Childhood, Harvard University Press, Cambridge.

Mayall B. (2008), Conversations with children. Working with generational issues, [in:] P. Christensen, A. James (eds.), Research with Children. Perspectives and practices, Routledge, Abingdon-New York.

Mayall B. (2013), A History of the Sociology of Childhood, UCL Institute of Education Press, London.

Morrison F., Cree V., Ruch G., Winter K.M., Hadfield M., Hallett S. (2019), Containment: exploring the concept of agency in children's statutory encounters with social workers, "Childhood: A Global Journal of Child Research", vol. 26(1), pp. 98-112.

Morrow V., Richards M. (1996), The ethics of social research with children: an overview, "Children \& Society", vol. 10(2), pp. 90-105.

O'Kane C. (2000), The development of participatory techniques facilitiating children's views about the decisions which affect them, [in:] P. Christensen, A. James (eds.), Research with Children: Perspectives and practices, Falmer Press, London, pp. 136-159. 
Prout A., James A. (1990), Constructing and Reconstructing Childhood: New directions in the sociological study of childhood, Falmer Press, New York.

Punch S. (2002), Research with children: the same or different from research with adults?, "Childhood: A Global Journal of Child Research", vol. 9(3), pp. 321-341.

Qvortrup J. (1993), Societal position of childhood: the international project Childhood as a Social Phenomenon, "Childhood: A Global Journal of Child Research", vol. 1(2), pp. 119-124.

Qvortrup J. (1997), A voice for children in statistical and social accounting: a plea for children's right to be heard, [in:] A. James, A. Prout (eds.), Constructing and Reconstructing Childhood: Contemporary issues in the sociological studies of childhood, Falmer, London.

Qvortrup J. (2007), Editorial: a reminder, "Childhood: A Global Journal of Child Research", vol. 14(4), pp. 395-400.

Radkowska-Walkowicz M., Reimann M. (2018a), Dzieci i zdrowie: wstęp do childhood studies: ksiązka dla dzieci, Oficyna Naukowa, Warszawa.

Radkowska-Walkowicz M., Reimann M. (2018b), Dzieci i zdrowie: wstep do childhood studies, Oficyna Naukowa, Warszawa.

Radkowska-Walkowicz M., Reimann M. (2019), Zespót Turnera: głosy i doświadczenia: książka dla dzieci, Oficyna Naukowa, Warszawa.

Raffety E.L. (2015), Minimizing social distance: participatory research with children, "Childhood: A Global Journal of Child Research", vol. 22(3), pp. 409-422.

Rose N.S. (1999), Governing The Soul: The shaping of the private self, Free Association Books, London.

Sargeant J., Harcourt D. (2012), Doing Ethical Research with Children, McGraw-Hill Education, Maidenhead.

Sinclair R. (2004), Participation in practice: making it meaningful, effective and sustainable, "Children \& Society", vol. 18(2), pp. 106-118.

Spyrou S. (2016), Researching children's silences: exploring the fullness of voice in childhood research, "Childhood: A Global Journal of Child Research", vol. 23(1), pp. 7-21.

Thomas N. (2017), Turning the tables. Children as researchers, [in:] P. Christensen, A. James (eds.), Research with Children. Perspectives and practices, 3rd ed., Routledge, London.

Tisdall E.K.M., Punch S. (2012), Not so "new"? Looking critically at childhood studies, "Children's Geographies", vol. 10(3), pp. 249-264, https://doi.org/10.1080/14733285.2012.693376

Warzywoda-Kruszyńska W. (2014), Dzieci i młodzież w Unii Europejskiej - dyskryminowana generacja?, "Przegląd Socjologiczny", vol. LXIII(2), pp. 125-141.

Water T. (2018), Ethical issues in participatory research with children and young people, [in:] I. C o y n e, B. C arter (eds.), Being Participatory: Researching with children and young people co-constructing knowledge using creative techniques, Springer International Publishing, Switzerland.

W e 11 e r S. (2006), Tuning-in to teenagers! Using radio phone-in discussions in research with young people, "International Journal of Social Research Methodology", vol. 9(4), pp. 303-315.

Wilkinson C., Wilkinson S. (2018), Principles of participatory research, [in:] I. Coyne, B. Carter (eds.), Being Participatory: Researching with children and young people co-constructing knowledge using creative techniques, Springer International Publishing, Switzerland.

Zalewska-Królak A. (2019), Badania dzieci. Trudności oraz wskazówki pomagające je przezwyciężyć, "Ogrody Nauk i Sztuk", no. 9, pp. 63-74. 


\section{Online sources}

http://childhoods.uw.edu.pl/ (accessed 5.07.2019).

http://nuffieldbioethics.org/project/children-research (accessed 10.07.2019).

http://nuffieldbioethics.org/report/children-and-clinical-research-ethical-issues/whats-differentabout-research-with-children-and-young (accessed 16.07.2019).

http://nuffieldbioethics.org/report/children-and-clinical-research-ethical-issues/inviting-childrenand-young-people-to-take-part (accessed 16.07.2019).

http://participatesdgs.org/?s=digital+storytelling (accessed 16.07.2019).

http://wels.open.ac.uk/research/childrens-research-centre (accessed 16.07.2019).

http://www.new-urbanism-india.com/map-my-community.php (accessed 16.07.2019).

https://ec.europa.eu/social/main.jsp?catId=1060\&langId=en (accessed 15.09.2020).

https://op.europa.eu/en/publication-detail/-/publication/3f3c50b2-6a24-465e-b8d1-74dcac7f8c42/

language-en/format-PDF/source-search (accessed 15.09.2020).

https://sjp.pwn.pl/szukaj/partycypacja.html (accessed 20.07.2019).

https://www.gov.pl/web/edukacja/praca-mlodziez-raport (accessed 1.09.2020).

https://www.lacittadeibambini.org/en/ (accessed 16.07.2019).

https://www.lacittadeibambini.org/en/ (accessed 20.07.2019).

https://www.lacittadeibambini.org/en/international-network/ (accessed 16.07.2019).

https://www.lacittadeibambini.org/en/project/ (accessed 15.09.2019).

https://www.uclan.ac.uk/research/explore/groups/centre_young_people_participation.php

(accessed 16.07.2019).

https://www.youtube.com/watch?v=6yaKwLG_vlE (accessed 10.07.2019).

https://www.youtube.com/watch?v=6yaKwLG_vlE (accessed 16.07.2019).

https://www.youtube.com/watch?v=vFxt5nLen1w (accessed 16.07.2019).

https://www.youtube.com/watch?v=Wx4CbfpzFGA\&feature=youtu.be (accessed 16.07.2019).

\section{PARTYCYPACJA DZIECI W BADANIACH SPOLECZNYCH WPROWADZENIE DO ZAGADNIENIA}

\footnotetext{
Abstrakt. Perspektywa childhood studies istnieje w nauce od lat 90. Obecnie uznawana jest za paradygmat. Artykuł dotyczy jednego z założeń tej orientacji teoretycznej - partycypacji dzieci w badaniach. Analiza pojęcia uwzględnia zarówno pozytywne, jak i krytyczne głosy pojawiające się w literaturze przedmiotu. Tekst zawiera analizę głównych założeń childhood studies oraz ich powiązania z partycypacyjnym podejściem do badań. Ponadto prezentuje rodzaje partycypacyjnych badań z dziećmi z uwzględnieniem stopnia uczestnictwa. Artykuł zawiera liczne przykłady zarówno przeprowadzonych badań, jak i konkretnych technik.

Slowa kluczowe: partycypacja dzieci w badaniach, sprawstwo, dziecko jako aktywny aktor społeczny, badania dzieci, badania z dziećmi, formy partycypacji, narzędzia partycypacyjne, childhood studies, nowa socjologia dzieciństwa.
} 